Original Article

\title{
Distribution, abundance and seasonality of scale insects in sugarcane crops in the state of São Paulo
}

\author{
Distribuição, abundância e sazonalidade de cochonilhas em culturas de \\ cana-de-açúcar no estado de São Paulo
}

\section{G. G. Monteiro ${ }^{a *}$ (D) A. L. B. G. Perontib (D) and N. M. Martinellia (B)}

aUniversidade Estadual Paulista - UNESP, Faculdade de Ciências Agrárias e Veterinárias, Departamento de Ciências da Produção Agrícola (Fitossanidade), Laboratório de Biossistemática de Hemiptera, Jaboticabal, SP, Brasil

bAutônomo, São Carlos, SP, Brasil

\begin{abstract}
In the state of São Paulo, the main sugarcane producing region of the world, two species of scale insects have frequently occurred, Aclerda takahashii (Kuwana, 1932) (Hemiptera: Aclerdidae) and Saccharicoccus sacchari (Cockerell, 1895) (Hemiptera: Pseudococcidae). To map the distribution and abundance of these species, 17 sugarcane producing fields, distributed in six mesoregions in São Paulo, were evaluated in August 2017 and, January, February, June and July 2018 during the ripening phase. The study on the seasonality of these species, by the presence or absence of the scale insects during the phenological cycle of the plant, was conducted between August 2017 and July 2018 in two sugarcane producing fields in the municipality of Jaboticabal, São Paulo, Brazil. The presence of S. sacchari was found in all the analyzed locations, and A. takahashii in twelve. Both scale insects showed significant difference of infestation in the node's region of the stems during the ripening phase in one of the studied locations. The aclerdid presented significant difference by infestation in one site during the ripening phase of the plant. The pseudococcid infested a greater number of nodes in the following phases of development; vegetative, grand growth and ripening in both studied areas, but it was in one site during the ripening phase that presented the greatest difference. Although the pink sugarcane mealybug was more abundant than A. takahashii in both studies, there were no patterns of relationships between the numbers of individuals to geographical locations and temperature.
\end{abstract}

Keywords: Aclerda takahashii, dispersion, population fluctuation, Saccharicoccus sacchari.

\begin{abstract}
Resumo
No estado de São Paulo, principal região produtora de cana-de-açúcar do mundo, duas espécies de cochonilhas têm ocorrido frequentemente, Aclerda takahashii (Kuwana, 1932) (Hemiptera: Aclerdidae) e Saccharicoccus sacchari (Cockerell, 1895) (Hemiptera: Pseudococcidae). Para mapear a distribuição e abundância destas espécies, 17 regiões produtoras de cana-de-açúcar, distribuídas em seis mesorregiões de São Paulo, foram avaliadas em agosto de 2017 e janeiro, fevereiro, junho e julho de 2018, durante a fase de maturação. O estudo da sazonalidade destas espécies, pela presença ou ausência das cochonilhas durante o ciclo fenológico da planta, foi conduzido entre agosto de 2017 e julho de 2018 em duas regiões produtoras de cana-de-açúcar no município de Jaboticabal, São Paulo, Brasil. Saccharicoccus sacchari foi encontrada em todas as localidades analisadas, e A. takahashii em 12. Ambas cochonilhas mostraram diferença significativa de infestação na região dos nós dos colmos durante a fase de maturação em uma das localidades estudadas. $\mathrm{O}$ aclerdídeo apresentou diferença significativa pela infestação em uma localidade durante a fase de maturação da planta. O pseudococcídeo infestou um grande número de nós nas seguintes fases de desenvolvimento; perfilhamento, crescimento vegetativo e maturação em ambas áreas estudadas, mas foi em uma localidade durante a fase de maturação que apresentou a maior diferença. Embora a cochonilha rosada da cana-de-açúcar foi mais abundante do que A. takahashii em ambos estudos, não houve padrões de relações entre o número de indivíduos com a localização geográfica e temperatura.
\end{abstract}

Palavras-chave: Aclerda takahashii, dispersão, flutuação populacional, Saccharicoccus sacchari.

\section{Introduction}

In Brazil 18 species of scale insects associated to sugarcane were reported, of which Aclerda takahashii (Kuwana, 1932) (Aclerdidae) and Saccharicoccus sacchari
(Cockerell, 1895) (Pseudococcidae) has been the most widely distributed (Silva et al., 1968; Oliz and Wolff, 2014; Zhang et al., 2018).

*e-mail: gabrielmonteiro7777@hotmail.com

Received: April 9, 2021 - Accepted: June 4, 2021 
Aclerda takahashii originated in Asian, was described from specimens collected in Taiwan (Kuwana, 1932). Currently, this species occurs in 13 countries distributed in the zoogeographical regions: (1) Nearctic, (1) Palearctic, (1) Neotropical, (8) Oriental and (2) Ethiopian (Morales et al., 2016). The aclerdid is associated to grassy plants of the genera Agropyron, Brachypodium, Milium, Miscanthus, Saccharum, Stipa and Thysanolaena (Morales et al., 2016).

In South America, A. takahashii is restricted to Brazil, where was first reported in the state of São Paulo, in 1932 (Silva et al., 1968), the largest sugarcane producer in the world (Embrapa, 2020). Later it was spread to the states of Pernambuco, Alagoas, Espírito Santo, Rio de Janeiro and Rio Grande do Sul and in the Federal District (Oliz and Wolff, 2014; Morales et al., 2016).

Information on this aclerdid is based on its original description (Kuwana, 1932), immature stages (Karam, 1991) and distribution (McConnell, 1954; Muniappan, 2001; Oliz and Wolff, 2014). According to Lim and Pan (1976), injuries are relatively non-damaging to sugarcane. However, in Guam island on vetiver plants, Vetiveria zizanioides (Linnaeus) (Poales: Poaceae), infested by this insect, necrosis and discoloration on the stem and large amount of fumagine on the honeydew were observed (Muniappan, 2001).

Saccharicoccus sacchari was described from specimens collected in Trinidad and Tobago (Cockerell, 1895), however there are still doubts about its possible center of origin (Zhang et al., 2018). This species is widely distributed, 79 countries distributed in six zoogeographical regions: (3) Nearctic, (5) Palearctic, (34) Neotropical, (13) Oriental, (14) Ethiopian and (10) Australian (Morales et al., 2016). The pseudococcid was registered on 18 host plants distributed in the families: Arecaceae, Caricaceae and Poaceae, been more frequently mentioned on sugarcane (Morales et al., 2016).

In Brazil, this species was reported in the states of Amazonas, Pará, Paraíba, Pernambuco, Minas Gerais, Mato Grosso, Rio de Janeiro, São Paulo and Santa Catarina (Silva et al., 1968; Morales et al., 2016).

Under laboratory conditions, the pseudococcid has four to five generations per year; with shorter life cycles when reared at $20^{\circ} \mathrm{C}$ (Kalra and Sidhu, 1964). In India, its presence in sugarcane slowed the growth of the plant, and caused the death of newly planted sheets (Yakoub, 2012). This insect can also cause a reduction in stem diameter and weight, and reduction in sugar by up to $21 \%$, in addition to acting as a vector for the bacilliform sugarcane virus (BSCV) (Atiqui and Murad, 1992; Mohamed et al., 2009; Victoria et al., 2005).

Aclerda takahashii and S. sacchari preferentially infest the region nodes of the stem, under the leaf sheath (Bonnett and Hewitt, 2005; Stocks, 2016). In addition, the pseudococcid can infest the roots (Kalra and Sidhu, 1964; Inkerman et al., 1986; Bonnett and Hewitt, 2005). Inkerman et al. (1986) described that the nymphs reach the aerial part of the plant, after their sprouting, settling in the region nodes under the sheaths.

Due to this cryptic habit, scale insects are rarely dispersed through wind or water, and their control becomes difficult (Rajendra, 1974; Inkerman et al., 1986;
Qin et al., 2017). However, in this case, ants play an important role, as they feed on excreted honeydew and carry them to neighboring plants (Rajendra, 1974). Other ways of dispersion may be due to agricultural practices, such as jet-transported equipment (Inkerman et al., 1986). The pseudococcid can also be dispersed by planting nymphinfested sheets (Inkerman et al., 1986).

Probably due to its greater distribution in the globe, $S$. sacchari has been better studied in relation to bioecological aspects, as well as its impacts on sugarcane fields (Atiqui and Murad, 1992; Mohamed et al., 2009; Victoria et al., 2005; Zhang et al., 2018). The population dynamics of this insect was studied in Australia during a five-year period, 1999 to 2003 (Bonnett and Hewitt, 2005). These authors found that in the months of January and February, corresponding to the end of summer, there were greater population peaks, varying from one year to another, and among the different studied sites. Bonnett and Hewitt (2005) attributed these irregularities to climatic conditions, the warmer months, and to different agricultural practices in the studied regions.

Knowledge about the occurrence and distribution of pest species in a given geographical location is of great importance, as legal measures can be taken to prevent their transport to free areas of these organisms. However, studies on its seasonality and population density, in a given region, are fundamental for the establishment of action related to integrated pest management.

Therefore, this study analyzed the distribution and abundance of $A$. takahashii and $S$. sacchari in sugarcane plants in the ripening phase in the state of São Paulo, and the seasonality of both species by the presence of them in all phenological phases in two sites in Jaboticabal, São Paulo, Brazil.

\section{Material and Methods}

\subsection{Studied areas}

The distribution and abundance of the scale insects were analyzed in 17 sugarcane producing fields, distributed in six mesoregions in the state of São Paulo, Brazil (Figure 1). The evaluations were carried out in the months of August 2017, and January to March and June and July 2018, corresponding to the ripening phase of the crop, before harvest. The locations are followed by the coordinates; (1) mesoregion of São José do Rio Preto (Pindorama $-21^{\circ} 24^{\prime} 36^{\prime \prime} \mathrm{S},-48^{\circ} 89^{\prime} 34^{\prime \prime} \mathrm{W}$, altitude of $527 \mathrm{~m}$; Nova Aliança $-21^{\circ} 00^{\prime} 86^{\prime \prime} \mathrm{S},-49^{\circ} 50^{\prime} 68^{\prime \prime} \mathrm{W}$, altitude of $464 \mathrm{~m}$; Votuporanga - $20^{\circ} 43^{\prime} 94^{\prime \prime} \mathrm{S},-50^{\circ} 00^{\prime} 69^{\prime \prime} \mathrm{W}$, altitude of $525 \mathrm{~m}$; Jales $-20^{\circ} 28^{\prime} 10^{\prime \prime} \mathrm{S},-50^{\circ} 52^{\prime} 49^{\prime \prime} \mathrm{W}$, altitude of $478 \mathrm{~m}$ ), (2) mesoregion of Ribeirão Preto (Jaboticabal $-21^{\circ} 23^{\prime} 44^{\prime \prime} \mathrm{S}$, $-48^{\circ} 34^{\prime} 08^{\prime \prime} \mathrm{W}$, altitude of $605 \mathrm{~m}$; Franca $-20^{\circ} 59^{\prime} 66^{\prime \prime} \mathrm{S}$, $-47^{\circ} 39^{\prime} 97^{\prime \prime} \mathrm{W}$, altitude $1040 \mathrm{~m}$; Taquaral $-21^{\circ} 07^{\prime} 54^{\prime \prime} \mathrm{S}$, $-48^{\circ} 40^{\prime} 21^{\prime \prime} \mathrm{W}$, altitude of $643 \mathrm{~m}$ ), (3) mesoregion of Bauru (Pongaí $-21^{\circ} 74^{\prime} 33^{\prime \prime} \mathrm{S},-49^{\circ} 35^{\prime} 16^{\prime \prime} \mathrm{W}$, altitude of $422 \mathrm{~m}$ ), (4) mesoregion of Araraquara (Água Vermelha -21 $90^{\circ} 10^{\prime \prime}$ S, $-47^{\circ} 88^{\prime} 85^{\prime \prime} \mathrm{W}$, altitude of $729 \mathrm{~m}$; São Carlos $-22^{\circ} 08^{\prime} 10^{\prime \prime}$ $\mathrm{S},-47^{\circ} 89^{\prime} 48^{\prime \prime} \mathrm{W}$, altitude of $856 \mathrm{~m}$; Itápolis $-21^{\circ} 58^{\prime} 90^{\prime \prime}$ S, $-48^{\circ} 82^{\prime} 92^{\prime \prime} \mathrm{W}$, altitude of $\left.487 \mathrm{~m}\right),(5)$ mesoregion of 


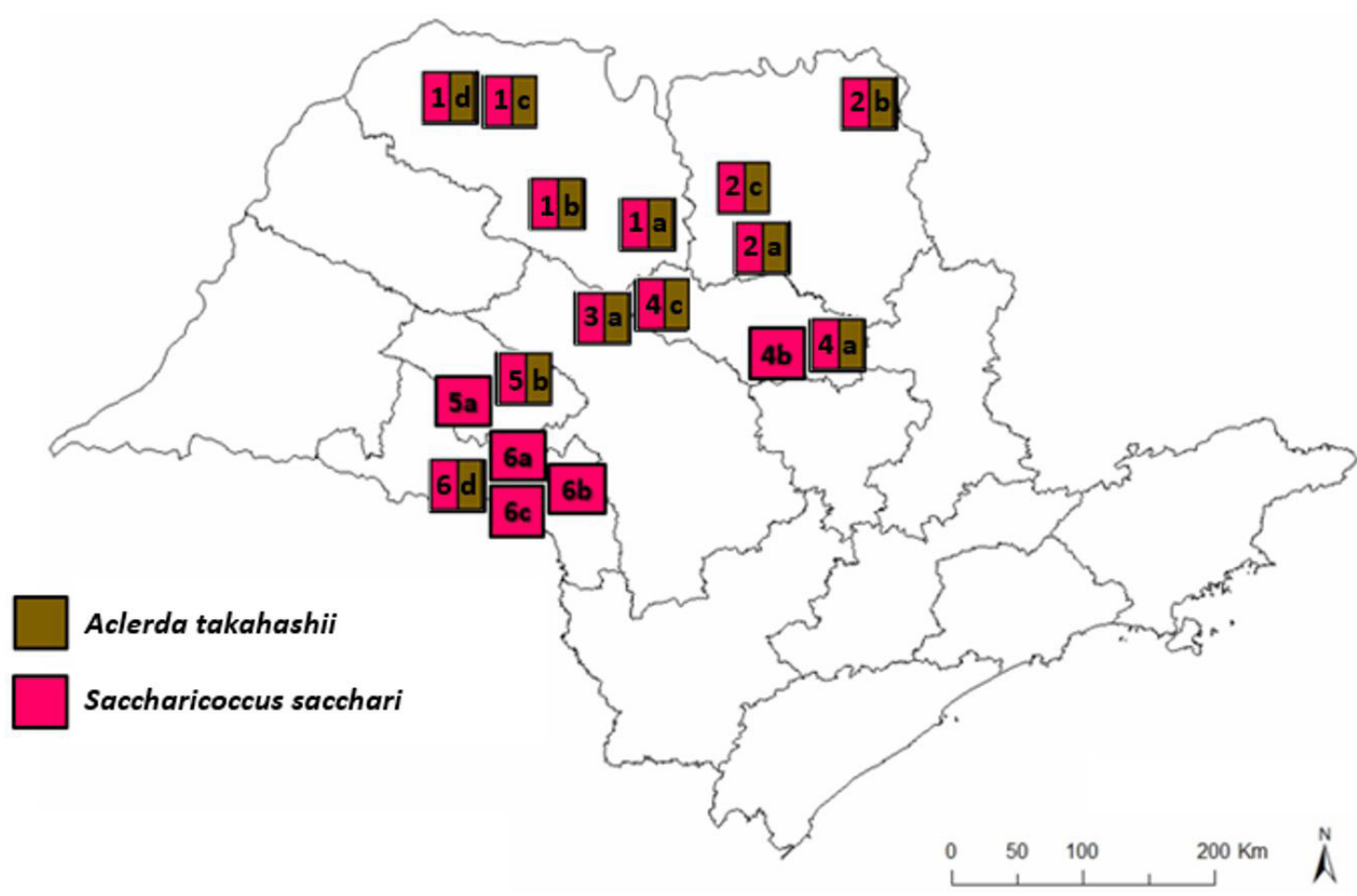

Figure 1. Distribution of Aclerda takahashii (12) and Saccharicoccus sacchari (17) in locations in the state of São Paulo, Brazil. Legend (1a) Pindorama, (1b) Nova Aliança, (1c) Votuporanga, (1d) Jales; (2a) Jaboticabal, (2b) Franca, (2c) Taquaral; (3a) Pongaí; (4a) São Carlos, (4b) Água Vermelha, (4c) Itápolis; (5a) Echaporã, (5b) Marília; (6a) Platina, (6b) Palmital, (6c) Cândido Mota, (6d) Assis.

Marília (Echaporã $-22^{\circ} 47^{\prime} 29^{\prime \prime} \mathrm{S},-50^{\circ} 32^{\prime} 32^{\prime \prime} \mathrm{W}$, altitude of $700 \mathrm{~m}$; Marília $-22^{\circ} 09^{\prime} 26^{\prime \prime} \mathrm{S},-49^{\circ} 90^{\prime} 20^{\prime \prime} \mathrm{W}$, altitude of $660 \mathrm{~m}$ ), and (6) mesoregion of Assis (Platina $-22^{\circ} 62^{\prime} 87^{\prime \prime}$ $\mathrm{S},-50^{\circ} 20^{\prime} 19^{\prime \prime} \mathrm{W}$, altitude of $466 \mathrm{~m}$; Palmital $-22^{\circ} 77^{\prime} 94^{\prime \prime} \mathrm{S}$, $-50^{\circ} 22^{\prime} 88^{\prime \prime} \mathrm{W}$, altitude of $508 \mathrm{~m}$; Cândido Mota -22 $72^{\circ} 55^{\prime \prime}$ $\mathrm{S},-50^{\circ} 37^{\prime} 42^{\prime \prime} \mathrm{W}$, altitude of $479 \mathrm{~m}$; Assis $-22^{\circ} 65^{\prime} 04^{\prime \prime} \mathrm{S}$, $-50^{\circ} 36^{\prime} 97^{\prime \prime} \mathrm{W}$, altitude of $543 \mathrm{~m}$ ).

For the seasonality study, monthly collections of scale insects were made between August 2017 and July 2018 , in two sugarcane producing fields, located in the municipality of Jaboticabal, São Paulo, Brazil, followed by the coordinates; (site 1 ) $-21^{\circ} 13^{\prime} 22^{\prime \prime} \mathrm{S},-48^{\circ} 16^{\prime} 81^{\prime \prime} \mathrm{W}$, altitude of $608 \mathrm{~m}$, and (site 2 ) $-21^{\circ} 17^{\prime} 31^{\prime \prime} \mathrm{S},-48^{\circ} 18^{\prime} 63^{\prime \prime}$ $\mathrm{W}$, altitude of $614 \mathrm{~m}$. All phenological phases of the plant, under the same clumps, were evaluated.

\subsection{Experimental design}

To dimension the species in the sugarcane producing fields in the state of São Paulo, an adapted technique described by Bonnett and Hewitt (2005) was used. Ten sugarcane plants from the edge of the crop, cultivar RB86 7515, five meters apart from each other, were randomly selected and evaluated. The leaves were tilted until the stem area was exposed, making it possible to observe the individuals with the naked eye. The nodes of the stem infested by scales insects were counted, observing the presence or absence of A. takahashii and S. sacchari, in the phases of the third instar nymph and adult.
For the evaluation of the statistical analysis, the data were submitted in completely randomized design (CRD) with 17 treatments and 10 replicates for the analysis of distribution and abundance of scale insects in the sugarcane producing fields on ripening phase distributed in the state of São Paulo, Brazil, and 12 treatments and 10 replicates for the analysis of the seasonality of scale insects in all phenological phases of the plants in each site in the municipality of Jaboticabal, São Paulo, Brazil, for each species. The program used was SAS ${ }^{\circledR}$ University Edition, version 9.4. The data, number of nodes infested with scale insects were submitted to Bartlett's tests to verify homocedasticity (PROC GLM) and Cramer von Mises's test for normality (PROC UNIVARIATE). The data showed normality in this way the Analysis of Variance (PROC ANOVA) was conducted. The means (PROC MEANS) when significant were compared using the Tukey test ( $p$ $<0.05$ ) (Everitt and Hothorn, 2005).

\subsection{Identification and deposit of voucher species}

To confirm the species, samples were collected in the field and mounted on permanent slides using the technique described by Willink (1990). The identification took place under an optical microscope through morphological characteristics using the works of McConnell (1954) for A. takahashii and Williams and Willink (1992) for S. sacchari.

The voucher species were deposited in the Reference Collection of Insects and Mites (CRIA) of the Department 
of Agricultural Production Sciences of the FCAV/UNESP, Jaboticabal, São Paulo, Brazil.

\section{Results}

\subsection{Distribution and abundance of Aclerda takahashii and} Saccharicoccus sacchari

Saccharicoccus sacchari was best distributed, being present in all locations in the state of São Paulo, while $A$. takahashii was observed in 12 (see Figure 1).

Regarding the abundance of species in the evaluated sugarcane producing fields, A. takahashii infested 2.6 nodes in São Carlos, providing statistical difference for the other locations that did not differ from each other (as shown in Table 1).

The population of Saccharicoccus sacchari differed in high incidence in Votuporanga, infesting 3.0 nodes of the analyzed plants (as shown in Table 1).

\subsection{Seasonality of Aclerda takahashii and Saccharicoccus sacchari}

Regarding the two analyzed sugarcane producing fields in Jaboticabal, the population of A. takahashii was more abundant in site 1, in March 2018, ripening phase (see Figure 2). The aclerdid infested 0.5 nodes of the plants, with a significant difference for the other analyzes that did not differ from each other (as shown in Table 2).

The pseudococcid was more abundant in site 2 in August 2017, ripening phase (see Figure 3). Saccharicoccus

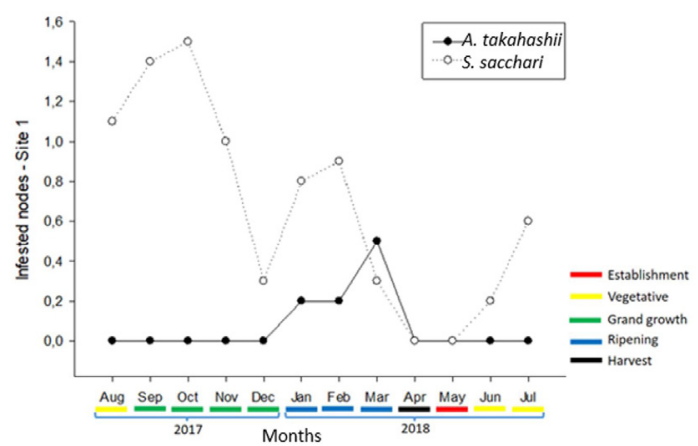

Figure 2. Infested nodes for both species in the site 1 in the phenological of sugarcane plants.

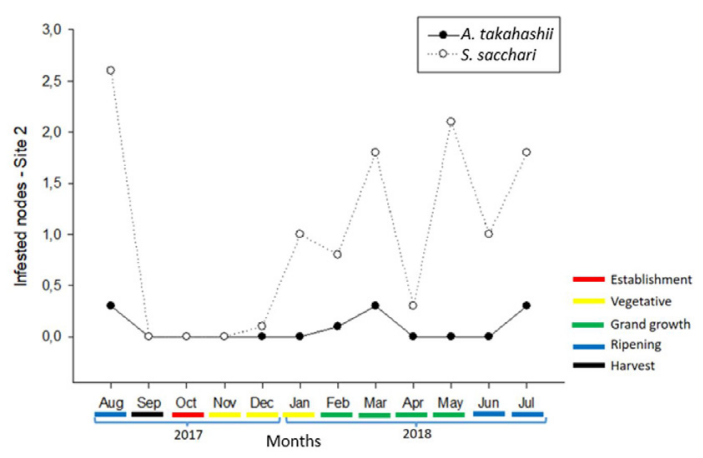

Figure 3. Infested nodes for both species in the site 2 in the phenological of sugarcane plants.

Table 1. Infested nodes with scale insects, by locations in the state of São Paulo, Brazil, in the ripening phase.

\begin{tabular}{ccc}
\hline Locations & Aclerda takahashii & Saccharicoccus sacchari \\
\hline Pindorama & $0.9 \pm 0.27 \mathrm{ac} *$ & $0.3 \pm 0.21 \mathrm{c}^{*}$ \\
Nova Aliança & $0.2 \pm 0.13 \mathrm{a}$ & $0.6 \pm 0.26 \mathrm{c}$ \\
Votuporanga & $1.3 \pm 0.51 \mathrm{ac}$ & $3.0 \pm 0.39 \mathrm{~b}$ \\
Jales & $1.3 \pm 0.51 \mathrm{ac}$ & $1.0 \pm 0.36 \mathrm{c}$ \\
Água Vermelha & $0.0 \pm 0.00 \mathrm{a}$ & $0.9 \pm 0.27 \mathrm{c}$ \\
São Carlos & $2.6 \pm 0.65 \mathrm{~b}$ & $2.5 \pm 0.63 \mathrm{ab}$ \\
Platina & $0.0 \pm 0.00 \mathrm{a}$ & $0.3 \pm 0.15 \mathrm{c}$ \\
Palmital & $0.0 \pm 0.00 \mathrm{a}$ & $0.3 \pm 0.15 \mathrm{c}$ \\
Cândido Mota & $0.0 \pm 0.00 \mathrm{a}$ & $0.7 \pm 0.21 \mathrm{c}$ \\
Assis & $0.1 \pm 0.10 \mathrm{a}$ & $0.9 \pm 0.23 \mathrm{c}$ \\
Echaporã & $0.0 \pm 0.00 \mathrm{a}$ & $1.6 \pm 0.33 \mathrm{ac}$ \\
Marília & $0.2 \pm 0.13 \mathrm{a}$ & $1.5 \pm 0.34 \mathrm{ac}$ \\
Pongaí & $1.8 \pm 0.41 \mathrm{c}$ & $1.6 \pm 0.37 \mathrm{ac}$ \\
Itápolis & $0.3 \pm 0.15 \mathrm{a}$ & $1.5 \pm 0.22 \mathrm{ac}$ \\
Jaboticabal & $0.3 \pm 0.21 \mathrm{a}$ & $2.5 \pm 0.34 \mathrm{ab}$ \\
Franca & $0.1 \pm 0.10 \mathrm{a}$ & $0.6 \pm 0.26 \mathrm{c}$
\end{tabular}

Aclerda takahashii $(\mathrm{F}=0.52 ; \mathrm{df}=16 ; p<0.001)$; Saccharicoccus sacchari $(\mathrm{F}=2.18 ; \mathrm{df}=16 ; p<0.001)$. "Means \pm standard error followed by the same letter in the same column do not differ by Tukey test $(p>0.05)$. 
Table 2. Infested nodes with scale insects, by sites in the municipality of Jaboticabal, São Paulo, Brazil.

\begin{tabular}{|c|c|c|c|c|}
\hline \multirow{2}{*}{ Period } & \multicolumn{2}{|c|}{ Aclerda takahashii } & \multicolumn{2}{|c|}{ Saccharicoccus sacchari } \\
\hline & Site 1 & Site 2 & Site 1 & Site 2 \\
\hline Aug/17 & $0.0 \pm 0.00 \mathrm{~b}^{*}$ & $0.3 \pm 0.21 \mathrm{a}^{*}$ & $1.1 \pm 0.27 a b^{*}$ & $2.6 \pm 0.33 b^{*}$ \\
\hline Sep/17 & $0.0 \pm 0.00 \mathrm{~b}$ & $0.0 \pm 0.00 \mathrm{a}$ & $1.4 \pm 0.33 b$ & $0.0 \pm 0.00 c$ \\
\hline Oct $/ 17$ & $0.0 \pm 0.00 \mathrm{~b}$ & $0.0 \pm 0.00 \mathrm{a}$ & $1.5 \pm 0.26 b$ & $0.0 \pm 0.00 c$ \\
\hline Nov/17 & $0.0 \pm 0.00 \mathrm{~b}$ & $0.0 \pm 0.00 \mathrm{a}$ & $1.0 \pm 0.25 \mathrm{abc}$ & $0.0 \pm 0.00 c$ \\
\hline Dec17 & $0.0 \pm 0.00 \mathrm{~b}$ & $0.0 \pm 0.00 \mathrm{a}$ & $0.3 \pm 0.15 \mathrm{ac}$ & $0.1 \pm 0.10 c$ \\
\hline Jan/18 & $0.2 \pm 0.13 b$ & $0.0 \pm 0.00 \mathrm{a}$ & $0.8 \pm 0.24 \mathrm{abc}$ & $1.0 \pm 0.42 \mathrm{ac}$ \\
\hline Feb/18 & $0.2 \pm 0.13 b$ & $0.1 \pm 0.10 \mathrm{a}$ & $0.9 \pm 0.31 \mathrm{abc}$ & $0.8 \pm 0.35 \mathrm{ac}$ \\
\hline Mar/18 & $0.5 \pm 0.22 \mathrm{a}$ & $0.3 \pm 0.21 \mathrm{a}$ & $0.3 \pm 0.15 \mathrm{ac}$ & $1.8 \pm 0.55 \mathrm{ab}$ \\
\hline Apr $/ 18$ & $0.0 \pm 0.00 \mathrm{~b}$ & $0.0 \pm 0.00 \mathrm{a}$ & $0.0 \pm 0.00 c$ & $0.3 \pm 0.21 c$ \\
\hline May/18 & $0.0 \pm 0.00 \mathrm{~b}$ & $0.0 \pm 0.00 \mathrm{a}$ & $0.0 \pm 0.00 c$ & $2.1 \pm 0.48 \mathrm{ab}$ \\
\hline Jun/18 & $0.0 \pm 0.00 \mathrm{~b}$ & $0.0 \pm 0.00 \mathrm{a}$ & $0.2 \pm 0.13 \mathrm{ac}$ & $1.0 \pm 0.25 \mathrm{ac}$ \\
\hline $\mathrm{Jul} / 18$ & $0.0 \pm 0.00 \mathrm{~b}$ & $0.3 \pm 0.21 \mathrm{a}$ & $0.6 \pm 0.26 \mathrm{abc}$ & $1.8 \pm 0.44 \mathrm{ab}$ \\
\hline
\end{tabular}

Aclerda takahashii Site $1(\mathrm{~F}=0.63 ; \mathrm{df}=11 ; p<0.001)$, Site $2(\mathrm{~F}=1.04 ; \mathrm{df}=11 ; p<0.001) ;$ Saccharicoccus sacchari Site $1(\mathrm{~F}=3.31 ; \mathrm{df}=11 ; p<0.001)$, Site $2(\mathrm{~F}=4.06 ; \mathrm{df}=11 ; p<0.001)$. "Means \pm standard error followed by the same letter in the same column do not differ by Tukey test $(p>0.05)$.

sacchari infested 2.6 nodes, but there were no significant differences among analyzes (as shown in Table 2).

\section{Discussion}

Saccharicoccus sacchari was found to be better distributed and infesting more nodes in the sugarcane fields in the state of São Paulo compared to A. takahashii. Although the aclerdid was registered in a few locations as to the pseudococcid, it was at least found in one location in each geopolitical mesoregion in the state of São Paulo.

The wider distribution and quantity of infested nodes found for $S$. sacchari in relation to A. takahashii may be related mainly to its more efficient dispersion. The pseudococcid can survive on newly-planted and/or cut sheets, having been observed infesting sheets at a depth of 30 centimeters (Sartiami et al., 2017). These, before migrating to the aerial part of the plants, can also infest the roots; whereas $A$. takahashii has been observed only in the node's regions, in the aerial part of Saccharum spp. (Oliz and Wolff, 2014). In addition, S. sacchari apparently produces more honeydew than $A$. takahashii, probably attracting a greater number of protective ants against natural enemies. However, for both species Cruz et al. (2019) found a significant number of associated natural enemies, ten for A. takahashii and 12 for S. sacchari.

As for the seasonality of the two species in the municipality of Jaboticabal, São Paulo, Brazil, the most abundantly recorded specimens show an appearance pattern at the phenological phases of the plants. In site 1 , the aclerdid was more present in the month of March 2018 , referring to the phenological phase of ripening, and in site 2 , there was no significant difference in appearance, however its greatest record was found in the same period, however plants in the intermediate phenological phase of grand growth. In turn, the pink sugarcane mealybug on site 1, infested more nodes in the months of September and October 2017, with plants referring to the initial phenological phase of grand growth, while on site 2 , its greatest record was in the final phenological phase of ripening, preceding the harvest. According to INMET (2018) the sugarcane producing fields of Jaboticabal presented, at the time of analysis, precipitation $0 \mathrm{~mm}$, and average temperature of; $15.6{ }^{\circ} \mathrm{C}, 16.6{ }^{\circ} \mathrm{C}, 20.0{ }^{\circ} \mathrm{C}$ and $19.4{ }^{\circ} \mathrm{C}$, consecutively for the months of August, September and October 2017 and March 2018. Although there is no information on the optimal temperature for the development of A. takahashii, however S. sacchari, according to Kalra and Sidhu (1964), the optimal reproduction temperature of the species is $20^{\circ} \mathrm{C}$, which may have favored its registration in these locations. However, studies conducted by Bonnett and Hewitt (2005) in Australia did not demonstrate a seasonal distribution relationship, as it was registered that although in summer, the warmest period of the year, which was expected to have the largest population peaks, similar to what was observed in this study, populations of both lower species in relation to the months of December 2017 and January and February 2018. During this period, the rains probably may have influenced the population dynamics of this species, since the plant accumulates water in the sheath, causing the scale insects to be killed by being immersed part of the time, or by the action of entomopathogenic fungi that are favored due to the high humidity. According to Mora-Lugo et al. (2015), entomopathogenic fungi as those of the genus Aspergillus are easily found in natural environments, and these infect scale insects, causing their death. However, the study does not present a relation of population dynamics of the species, favored or not by precipitation and average temperature.

The life cycle of insects is interrupted during the harvest period that occurs once a year, usually in the months of April and September. Therefore, the differences among the abundances for both species between the sampling sites in 
the municipality of Jaboticabal throughout the study period can be attributed to the different periods of harvest at the sites. For site 1, the harvest was in April 2017; and to site 2 , in September of the same year. In the harvest months and the two subsequent months, scale insects were not counted because they were absent. Although there is no information on the underground habit of A. takahashii, according to Kalra and Sidhu (1964) after the sugarcane harvest, the pink sugarcane mealybug survives at the root, under the soil, and as the plant grows, the mealybug will spread to the stem when they are ripe for sap sucking.

Aclerda takahashii and S. sacchari are widely distributed in the state of São Paulo, and although the pseudococcid has infested more nodes in the stems than the aclerdid, in both studies, there were no population dynamics relationships of both species to geographical locations and temperature.

\section{Acknowledgements}

This study was financed in part by the Coordination for the Improvement of Higher Education Personnel - Brazil (CAPES) - Financing Code 001.

\section{References}

ATIQUI, M.U.A. and MURAD, H., 1992. Assessment of loss in sucrose content of sugarcane due to sugarcane mealy bug, Saccharicoccus sacchari Ckll. Journal of Insect Science, vol. 5, pp. 196-197.

BONNETT, G.D. and HEWITT, M.L., 2005. Numbers of pink sugarcane mealy bug, Saccharicoccus sacchari (Cockerell) (Hemiptera: Pseudococcidae), differ within seasons and among regions and stages of the sugarcane crop cycle. Australian Journal of Entomology, vol. 44, no. 3, pp. 304-309. http://dx.doi. $\operatorname{org} / 10.1111 / \mathrm{j} .1440-6055.2005 .00480 . x$.

COCKERELL, T.D.A., 1895. A new mealy-bug on sugar cane.- Journal of the Trinidad Field Naturalists'. Club, vol. 2, pp. 195.

CRUZ, M.A., PERONTI, A.L.B.G., MARTINELLI, N.M., COSTA, V.A., IGNÁCIO, G.P. and ALMEIDA, L.M., 2019. Complex of natural enemies associated with scale insects (Hemiptera: Coccomorpha) on sugarcane in Brazil. The Journal of Agricultural Science, vol. 11, no. 4, pp. 160-175. http://dx.doi.org/10.5539/ jas.v11n4p160.

EMPRESA BRASILEIRA DE PESQUISA AGROPECUÁRIA - EMBRAPA [online], 2020 [viewed 25 November 2020]. Available from: http://www.embrapa.br

EVERITT, B.S. and HOTHORN, T., 2005. A handbook of statistical analyses using R.. London: Technometrics Press.

INKERMAN, P.A., ASHBOLT, N.J., CARVER, M. and WILLIAMS, D.J., 1986. Observations on the pink sugarcane in mealybug, Saccharicoccus sacchari (Cockerell), in Australia (Homoptera: Pseudococcidae). In: Universidad del Valle, ed. Spain: Boletin del Museo de Entomologia de la Universidad del Valle.

INSTITUTO NACIONAL DE METEOROLOGIA MINISTÉRIO DA AGRICULTURA PECUÁRIA E ABASTECIMENTO - INMET [online], 2018 [viewed 20 July 2018]. Available from: http://www.portal. inmet.gov.br
KALRA, A.N. and SIDHU, A.S., 1964. Sugarcane mealybug, Saccharicoccus sacchari $\mathrm{Ckll}$., and its control. Proceedings of the Indiana Academy of Sciences, vol. 5, pp. 557-559.

KARAM, H.H., 1991. Immature stages of Aclerda takahashii Kuwana (Homoptera: Coccoidea: Aclerdidae). Alexandria Journal of Agricultural Research, vol. 36, pp. 341-353.

KUWANA, S.I., 1932. The genus Aclerda in Japan, including Formosa. Philippine Journal of Science, vol. 48, pp. 57-66.

LIM, G.T. and PAN, Y.C., 1976. Parasites of the sugarcane scale insect Aclerda takahashii (Kuw.). Entomological News, vol. 3, pp. 1-4.

MCCONNELL, H.S., 1954. A classification of the coccid family Aclerdidae (Coccoidea, Homoptera). Bulletin of the Maryland Agriculture Experiment Station A., vol. 75, pp. 1-121.

MOHAMED, G.E., IBRAHIM, S. and MOHARUM, F., 2009. Effect of Saccharicoccus sacchari (Cockerell) infestation levels on sugarcane physical and chemical properties. Egyptian Academic Journal of Biological Science, vol. 2, no. 2, pp. 119-123. http:// dx.doi.org/10.21608/eajbsa.2009.15434.

MORA-LUGO, R., MADRIGAL, M., YELEMANE, V. and FERNANDEZLAHORE, M., 2015. Improved biomass and protein production in solid-state cultures of an Aspergillus sojae strain harboging the Vitreoscilla hemoglobin. Applied Genetics and Biotechnology, vol. 99, no. 22, pp. 9699-9708. PMid:26224427.

MORALES, M.G., DENNO, B.D., MILLER, D.R., MILLER, G.L., BENDOV, Y. and HARDY, N.B., 2016. ScaleNet: a literature-based model of scale insect biology and systematics. Database, vol. 2016, pp. bav118.

MUNIAPPAN, R., 2001. Scale insects on vetiver in Guam. Vetiver Newsletter, vol. 23, pp. 1-16.

OLIZ, C.B. and WOLFF, V.R.S., 2014. First record of Aclerda takahashii (Coccoidea; Aclerdidae) in Rio Grande do Sul, Brazil. Pesquisa Agropecuária Gaúcha, vol. 20, pp. 162-166.

QIN, Z.Q., WEI, J.J., SONG, X.P., LUO, Y.W., LIU, L. and DENG, Z.Y., 2017. Efficacy of the ladybird beetle Cryptolaemus montrouzieri Mulsant for control of Saccharicoccus sacchari (Cockerell). Sugar Tech, vol. 19, no. 6, pp. 599-603. http://dx.doi.org/10.1007/ s12355-017-0528-4.

RAJENDRA, A., 1974. The biology and control of Saccharicoccus sacchari Ckll. (Hom: Pseudococcidae) the pink mealy bug of sugar cane in Sri Lanka. Ceylon Journal of Science. Biological Sciences, vol. 11, pp. 23-28.

SARTIAMI, D., WATSON, G.W., ROFF, M.M.N. and IDRIS, A.B., 2017. A taxonomic update of Takahashi's historic collection of mealybugs (Hemiptera: Pseudococcidae) from Malaysia and Singapore. Serangga, vol. 22, pp. 91-114.

SILVA, R., GONÇALVES, C.R., GALVÃO, D., GONÇALVES, M., GOMES, J., SILVA, M.N. and SIMONI, L., 1968. Quarto catálogo dos insetos que vivem nas plantas do Brasil. Seus parasitos e predadores:

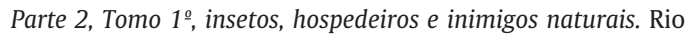
de Janeiro: Ministério da Agricultura.

STOCKS, I.C., 2016. The flat grass scale, Aclerda takahashii Kuwana (Hemiptera: Aclerdidae), a new pest of sugarcane in Florida. Pest Alert (Florida Department of Agriculture and Consumer Services Division of Plant Industry). FDACS, vol. 18, pp. 1-17.

VICTORIA, J.I., AVELLANEDA, M.C., ANGEL, J.C. and GUZMÁN, M.L., 2005. Resistance to Sugarcane yellow leaf virus in Colombia. International Society of Sugar Cane Technologists, vol. 25, pp. 664-670.

WILLIAMS, D.J. and WILLINK, M.C.G. 1992. Mealybugs of Central and South America. London, UK: CAB International. 
WILLINK, M.C.G., 1990. Knowing our fauna, I Superfamily Coccoidea (Homoptera: Sternorryncha) = Conociendo nuestra fauna, Superfamilia Coccoidea (Homoptera: Sternorryncha). Tucumán: Universidad Nacional de Tucumán Facultad de Ciencias Naturales e Instituto Miguel Lillo.

YAKOUB, R.S. 2012. Effect of infestation with pink sugarcane mealybug. Saccharicoccus sacchari Ckll. on the physical and chemical characters of sugarcane cultivars. Cairo: Faculty of Agricultural of Cairo University.

ZHANG, J.T., WU, B. and WU, S.A., 2018. A review of the genus Saccharicoccus Ferris, 1954 (Hemiptera: Coccomorpha: Pseudococcidae) in China, with description of a new species. Zootaxa, vol. 4375, no. 1, pp. 127-135. http://dx.doi.org/10.11646/ zootaxa.4375.1.7. PMid:29689784. 